\title{
Association of rumination time with subclinical ketosis in transition dairy cows
}

\author{
E. I. Kaufman, ${ }^{*}$ S. J. LeBlanc, $†$ B. W. McBride, ${ }^{*}$ T. F. Duffield, $†$ and T. J. DeVries ${ }^{* 1}$ \\ *Department of Animal Biosciences, and \\ †Department of Population Medicine, University of Guelph, 50 Stone Road East, Guelph, ON, N1G 2W1, Canada
}

\begin{abstract}
The objective of this study was to characterize the relationship between rumination and subclinical ketosis (SCK) in transition dairy cows. A study was conducted on 4 commercial dairy farms in eastern Ontario, Canada. A total of 339 Holstein dairy cows (107 primiparous and 232 multiparous) were monitored for rumination activity and SCK from $14 \mathrm{~d}$ before calving until 28 $\mathrm{d}$ after calving. Rumination was recorded daily using an automated monitoring system. A blood sample was taken from the coccygeal vein of each cow for measurement of $\beta$-hydroxybutyrate (BHB) once weekly throughout the 6 -wk observation period. Cows with $\mathrm{BHB} \geq 1.2 \mathrm{mmol} / \mathrm{L}$ in any of the 4 postpartum samples were considered to have SCK. Cases of retained placenta, metritis, milk fever, or mastitis during the study period were also recorded. Cows were categorized into 1 of 4 groups: healthy cows (HLT) that had no SCK or any other recorded health problem $(\mathrm{n}=139)$; cows treated for at least one health issue other than SCK (HLT+; $\mathrm{n}=50$ ); cows with SCK (hyperketonemia; HYK) with no other health problems during transition $(\mathrm{n}=97)$; or cows $(\mathrm{HYK}+)$ that had SCK and one or more other health problems $(\mathrm{n}=53)$. Daily rumination time was summarized by week and comparisons were made between HLT and HYK and HYK+. From 2 wk before calving (wk -2 ) to 4 wk after calving (wk $+4)$, there was no difference in rumination time (409 $\pm 9.8 \mathrm{~min} / \mathrm{d}$ ) among HLT, HYK, and HYK+ cows in their first lactation. Multiparous cows in HLT spent an average of $459 \pm 11.3 \mathrm{~min} / \mathrm{d}$ ruminating from wk -2 to wk +4 . Multiparous HYK cows ruminated $25 \pm$ $12.8 \mathrm{~min} / \mathrm{d}$ less than HLT cows, whereas HYK + cows ruminated $44 \pm 15.6 \mathrm{~min} / \mathrm{d}$ less than HLT cows. The largest differences in rumination time between HLT and HYK + cows were seen during wk $-1,+1$, and +2 , when HYK+ cows ruminated $48 \pm 17.2,73 \pm 16.0$,
\end{abstract}

Received October 10, 2015.

Accepted March 15, 2016.

${ }^{1}$ Corresponding author: tdevries@uoguelph.ca and $65 \pm 19.4 \mathrm{~min} / \mathrm{d}$ less than HLT cows, respectively. In multiparous cows, increased odds of HYK were associated with greater milk yield in the previous lactation, greater loss of body condition over the transition period, greater stall stocking density in wk -1 , and reduced rumination time in wk -1 . Increased odds of HYK + were associated with higher parity, longer dry period, greater stall stocking density in wk -1 , and reduced rumination time in wk +1 . These results suggest that rumination monitoring across the transition period might contribute to identification of SCK and other health problems in multiparous cows.

Key words: transition, rumination, hyperketonemia, automated monitoring

\section{INTRODUCTION}

The transition period commences 3 wk before calving and lasts until 3 wk after calving (Drackley, 1999). It is both a critical and vulnerable period for the dairy cow. Essentially all dairy cows experience a negative energy balance (NEB) in early lactation (Sovani et al., 2000), due to decreased DMI around calving and slower acceleration of DMI than of milk production (Grant and Albright, 1995; Schirmann et al., 2013). An excessive or prolonged decrease in DMI around calving may result in nonadaptive NEB, which may lead to subclinical ketosis (SCK; Grummer, 1995), also referred to as hyperketonemia (McArt et al., 2012).

McArt et al. (2012) reported an average cumulative SCK incidence of $43 \%$ among cows tested thrice weekly from 3 to 16 DIM, with the peak incidence at 5 DIM. This condition can result in lower milk production (McArt et al., 2012), reduced reproductive performance (Walsh et al., 2007), and increased risk of other illnesses, including fatty liver, displaced abomasum, and metritis (Suthar et al., 2013). Technological advancements have improved detection of SCK. Cows in NEB begin to mobilize fat stores in an attempt to meet the high energy demand during early lactation, which results in partial oxidation of fatty acids and releases ketone bodies (i.e., BHB) into the blood (Bauman and Currie, 1980; Goldhawk et al., 2009; LeBlanc, 
2010). An electronic cow-side test for the quantification of blood BHB concentration (Precision Xtra, Abbott Diabetes Care, Saint Laurent, QC, Canada), has been validated in dairy cows (Iwersen et al., 2009; Voyvoda and Erdogan, 2010), making on-farm diagnosis of SCK accurate and reliable.

The current challenge for producers is identifying SCK at an early stage. There is growing evidence that measurements of cow behavior can be used to identify cows at risk for illness (Weary et al., 2009). Huzzey et al. (2007) found that transition cows with decreased feed intake spent less time feeding before calving and were at an increased risk of developing metritis. It has been estimated that for every $1-\mathrm{kg}$ decrease in DMI and 10-min decrease in feeding time during the week before calving, the odds of developing SCK increase by 2.2 and 1.9 times, respectively (Goldhawk et al., 2009). Cows diagnosed with SCK have been observed to have lower rumination times than healthy cows in the first week after calving (Soriani et al., 2012; Liboreiro et al., 2015). There is conflicting evidence in the literature regarding the association between rumination time and blood BHB concentration. Liboreiro et al. (2015) did not find any association between these factors over the transition period; however, Soriani et al. (2013) did find a negative association of rumination time with blood BHB concentration in early lactation cows. Rumination behavior may be a promising indicator of metabolic conditions (Soriani et al., 2012), particularly during the postpartum period because it is likely affected by changes in feeding behavior and DMI (Okine and Mathison, 1991).

The objective of this study was to characterize changes in rumination behavior across the transition period and determine if rumination behavior might be used to identify cows at risk for SCK postcalving. We hypothesized that dairy cows with reduced rumination activity, both pre- and postcalving, would be at higher risk of experiencing SCK during early lactation.

\section{MATERIALS AND METHODS}

\section{Herd Selection}

This prospective observational study was conducted on 4 commercial dairy farms located in eastern Ontario, Canada, between March and October 2014. Herds were selected as a convenience sample according to proximity to the University of Guelph, Kemptville Campus (Kemptville, ON, Canada). Participating dairies milked between 125 and 400 Holstein cows (Table 1). All cows were housed in a freestall facility, fed a TMR $1 \times / d$, and milked in a parlor $3 \times / d$. Animal use, data collection, and study design were approved by the University of Guelph's Animal Care Committee (AUP\#2518) and Research Ethics Board (REB\#14JA015).

Table 1. Descriptive summary of farm-level variables for lactating cows in an observational study of the associations of rumination time from 2 wk before to 4 wk after calving and subclinical ketosis

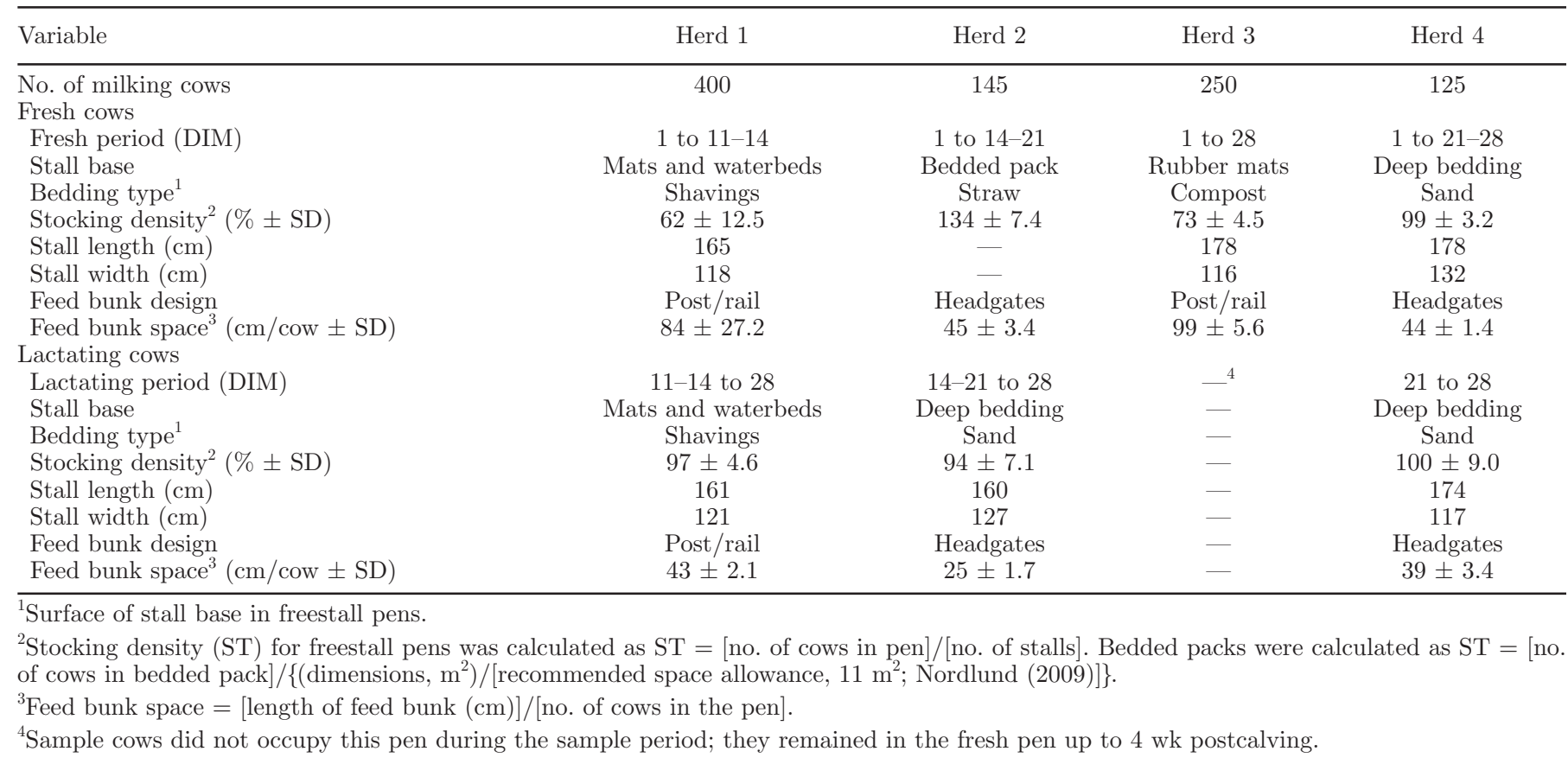


Researchers surveyed each participating producer during the first farm visit and recorded general farm information (herd size), as well as dry and fresh cow management practices (dry-off protocol, frequency of feed delivery and feed push up, and ionophore usage). At each weekly visit, the total number of cows in each pen were counted and recorded. Researchers measured feed bunk dimensions for all dry and fresh cow pens, and counted the number of stalls/pen to calculate stall stocking density available during each week of the transition period. Freestall stocking density was calculated by dividing the number of cows by the number of stalls in each pen $\times 100 \%$. Bedded pack stocking density was calculated by first dividing the pack dimensions $\left(\mathrm{m}^{2}\right)$ by the recommended space allowance for transition cows (11 $\mathrm{m}^{2}$; Nordlund, 2009), and dividing the number of cows in each bedded pack by this value $\times 100 \%$. Using this calculation, $100 \%$ stocking density in bedded packs was equivalent to providing $11 \mathrm{~m}^{2}$ of space per cow. Management and housing practices for lactating and dry cows are summarized in Tables 1 and 2, respectively. Ionophores were not used in the TMR of any of the herds, except herd 3, which added an ionophore to the close-up and fresh cow rations. All herds, except herd 1, gave monensin by controlled-release rumen bolus (Rumensin CRC, Elanco, Guelph, ON, Canada) precalving.

\section{Cow Enrollment}

Researchers obtained a list of expected calving dates from each participating farm at the first farm visit. Each week, cows were systematically enrolled in the study based on the availability of rumination collars and parity (1:2 ratio of primiparous to multiparous cows). Cows were enrolled 2 to $3 \mathrm{wk}$ before their expected calving date and at this time, individual animal information (cow identification number, parity, previous-lactation 305-d milk yield, dry-off date, expected calving date) was recorded. We aimed to study each cow from $2 \mathrm{wk}$ before calving until $4 \mathrm{wk}$ after calving. In total, 346 cows were monitored from an average of $-16 \pm 5.4 \mathrm{~d}$ (mean \pm SD; range: -34 to $-2 \mathrm{~d}$ ) until $+28 \mathrm{~d}$ relative to calving. We planned to screen a minimum of 300 cows; with an expected SCK incidence rate of $40 \%$, this would yield 120 cows with SCK. Given 95\% confidence and $80 \%$ power, estimates of variability from Soriani et al. (2012; estimated from all of their data to be a SD of $\sim 50 \mathrm{~min} / \mathrm{d}$ ), and assuming one-third of animals in the sample would be primiparous, this sample size was expected to allow for detection of a difference of $32 \mathrm{~min} / \mathrm{d}$ in rumination time with $\mathrm{SD}$ of $50 \mathrm{~min} / \mathrm{d}$ (Abramson, 2011) between cows with and without SCK within each parity category (i.e., $\geq 39$ primiparous animals with SCK to compare with $>39$ primiparous animals

Table 2. Descriptive summary of farm-level variables for far-off and close-up dry cows in an observational study of the associations of rumination time from 2 wk before to 4 wk after calving and subclinical ketosis

\begin{tabular}{|c|c|c|c|c|}
\hline Variable & Herd 1 & Herd 2 & Herd 3 & Herd 4 \\
\hline Far-off period (days before expected calving date) & 60 to $21-7$ & 60 to 14 & 60 to 21 & 60 to $21-14$ \\
\hline Stall base ${ }^{1}$ & Rubber mats & Deep bedding & Rubber mats & Deep bedding \\
\hline Stocking density $^{2}(\% \pm \mathrm{SD})$ & $109 \pm 12.7$ & $58 \pm 13.8$ & $106 \pm 26.9$ & $91 \pm 45.7$ \\
\hline Stall length $(\mathrm{cm})$ & 164 & 156 & 177 & 178 \\
\hline Stall width $(\mathrm{cm})$ & 119 & 130 & 119 & 125 \\
\hline Fresh feed delivery (no./d) & 1 & 1 & 1 & 1 \\
\hline Feed push-up frequency (no./d) & 6 & 6 & 5 & 5 \\
\hline \multicolumn{5}{|l|}{ Close-up dry cows } \\
\hline Close-up period (days before expected calving date) & $21-7$ to calving & 14 to calving & 21 to calving & $21-14$ to calving \\
\hline Stall base & Bedded pack & Bedded pack & Rubber mats & Bedded pack \\
\hline Bedding type & Straw & Straw & Compost & Straw \\
\hline Stocking density $^{2}(\% \pm \mathrm{SD})$ & $138 \pm 28.2$ & $58 \pm 23.3$ & $75 \pm 20.0$ & $115 \pm 34.4$ \\
\hline Feed push-up frequency $($ no./d) & 0 & 6 & 5 & 5 \\
\hline
\end{tabular}

${ }^{1}$ Surface of stall base in freestall pens.

${ }^{2}$ Stocking density $(\mathrm{ST})$ for freestall pens was calculated as $\mathrm{ST}=[$ no. of cows in pen $] /[$ no. of stalls $]$. Bedded packs were calculated as $\mathrm{ST}=[$ no. of cows in bedded pack $] /\left\{\left(\right.\right.$ dimensions, $\left.\mathrm{m}^{2}\right) /\left[\right.$ recommended space allowance, $11 \mathrm{~m}^{2} ;$ Nordlund $\left.\left.(2009)\right]\right\}$.

${ }^{3}$ Feed bunk space $=[$ length of feed bunk $(\mathrm{cm})] /[$ no. of cows in the pen] . 
without SCK. Among multiparous cows, 80 with SCK would provide the power to detect a difference of 23 $\mathrm{min} / \mathrm{d}$ in rumination with the same SD).

\section{Rumination Behavior}

An automated rumination monitoring system (HiTag, SCR Engineers Ltd., Netanya, Israel) was installed at each participating dairy farm. Each cow was fitted with an SCR rumination collar at enrollment, which monitored rumination $24 \mathrm{~h} / \mathrm{d}$, as validated for dairy cows by Schirmann et al. (2009), over the 6 -wk study period. The collars contained a small microphone that recorded each time a bolus was regurgitated, remasticated, and swallowed to determine total time spent ruminating during each 2 -h interval throughout the day. This information was transferred to the control unit via radio frequency or when collars were scanned by identification units located in high traffic areas (e.g., parlor exits or above water troughs). Data were backed up from the control unit and downloaded to the database weekly. The twelve 2 -h intervals each day were summed to determine total time spent ruminating per day per cow. If one 2 -h interval was not recorded by the system, the entire day was reported as a missing value.

\section{Subclinical Ketosis Diagnosis}

Each enrolled cow was assessed for SCK, both preand postcalving, $1 \times /$ wk over the 6 -wk study period for each cow. Samples were taken at the same time relative to feeding each week on every farm. Cows were restrained within 2 to $6 \mathrm{~h}$ after feeding in a stall or headlock to obtain a small blood sample from the coccygeal vein using a vacuum-sealed blood collection tube (Blood Collection Tube Vacutainer Glass $10 \mathrm{~mL}$, red; Becton Dickinson Canada Inc., Mississauga, ON, Canada) and 21-gauge needle (Needle Vacutainer Multiple Sample $21 \mathrm{G} \times 1$ in, Becton Dickinson Canada Inc.). The concentration of BHB in this whole-blood sample was tested immediately using an electronic handheld device (Precision Xtra meter, Abbott Diabetes Care), as validated by Iwersen et al. (2009). The BHB concentration of the blood was recorded on farm; cows with $\mathrm{BHB} \geq 1.2 \mathrm{mmol} / \mathrm{L}$ at one or more of the 4 postpartum samples were classified as having SCK (Geishauser et al., 1998; McArt et al., 2012).

\section{Determining Health Status}

Body condition score (1 to 5, following Wildman et al., 1982) and locomotion score (1 to 5, following Flower and Weary, 2006) were assessed at enrollment, 2 to 3 wk before the expected calving date; and at the end of the study period, 4 wk after calving. Cows were scored by 1 of 2 individuals at the time of enrollment and removal; interobserver reliability was determined between individuals to ensure validity of results (locomotion score: $\kappa=0.83$; BCS: $\kappa=0.84$ ).

Producers were asked to monitor and record the incidence of retained placenta, metritis, milk fever, displaced abomasum, and clinical mastitis using standardized definitions for these conditions. Cows were diagnosed with retained placenta if the placenta was present $>24 \mathrm{~h}$ after calving. Metritis was defined as a foul smelling vaginal discharge accompanied by rectal temperature $>39.5^{\circ} \mathrm{C}$ between 1 and 10 DIM. Cows with milk fever were treated with calcium according to clinical signs (i.e., down or unable to rise, cold extremities, or constipation). Mastitis was defined as visibly abnormal milk or udder, indicative of infection. Displaced abomasum was characterized as a gas-filled abomasum on the left or right side, diagnosed by a "ping" sound on percussion. Occurrences of these conditions during the 6 -wk study period for each cow were detected daily by farm staff and recorded.

Cows were categorized into 1 of 4 groups: healthy (HLT) cows had no SCK or any other recorded health problem; healthy cows that did not have SCK but were treated for at least one other health problem $(\mathbf{H L T}+)$; cows with SCK (hyperketonemia; HYK) but with no other health problems during the observation period; and cows that had SCK and one or more other health problems during the observation period $(\mathbf{H Y K}+)$.

\section{Ration Composition}

Feed samples of the close-up dry cow ration and fresh cow ration were collected twice each month by the producers at each farm. At each sampling, individual samples were taken from 10 different areas of the feed bunk and combined into 1 sample of each diet per farm per sample day to ensure a representative sample. Feed samples were collected directly after fresh feed delivery and were immediately frozen. Research staff picked up the samples at the next farm visit and returned these to the University of Guelph, Kemptville Campus, where they were kept frozen at $-20^{\circ} \mathrm{C}$ until nutrient analysis.

Samples for DM were weighed and then dried at $55^{\circ} \mathrm{C}$ for $48 \mathrm{~h}$. After drying, each sample was weighed again to calculate the percentage DM of each close-up dry cow and fresh cow ration. After drying, samples were ground to fit through a 1-mm screen (Wiley mill, Arthur H. Thomas Co., Philadelphia, PA). Samples of each diet at each farm were pooled into 3 samples (May-June, June-July, and August-October); only samples from the same ration formulation were pooled together. Pooled samples were sent to Cumberland 
Table 3. Feed analysis ${ }^{1}$ summary for close-up dry cow and fresh cow feed rations at each participating dairy farm in an observational study of the associations of rumination time and subclinical ketosis over the transition period

\begin{tabular}{lcccc}
\hline Ration component & Herd 1 & Herd 2 & Herd 3 & Herd 4 \\
\hline Close-up dry cow ration & & & & \\
DM (\%) & 46.6 & 46.6 & 43.1 & 45.7 \\
NDF (\% of DM) & 38.4 & 37.5 & 33.3 & 41.1 \\
ADF (\% of DM) & 26.2 & 23.9 & 23.0 & 25.9 \\
NFC (\% of DM) & 30.0 & 32.1 & 34.5 & 31.8 \\
CP (\% of DM) & 15.4 & 14.6 & 15.8 & 12.5 \\
NE $($ Mcal/kg) & 1.5 & 1.4 & 1.5 & 1.4 \\
Fresh cow ration & & & & 44.7 \\
DM (\%) & 47.8 & 45.9 & 48.6 & 29.2 \\
NDF (\% of DM) & 32.2 & 27.8 & 27.6 & 19.7 \\
ADF (\% of DM) & 21.8 & 19.2 & 18.6 & 40.3 \\
NFC (\% of DM) & 36.7 & 38.1 & 39.4 & 1.7 \\
CP (\% of DM) & 15.0 & 17.9 & 16.6 & 1.6 \\
NE (Mcal/kg) & 1.6 & 1.6 & 1.6 & \\
\hline
\end{tabular}

${ }^{1}$ Values were obtained from chemical analysis of feed samples. NFC $=100-(\% \mathrm{CP}+\% \mathrm{NDF}+\%$ fat $+\%$ ash); $\mathrm{NE}_{\mathrm{L}}$ was calculated based on NRC (2001) equations.

Valley Analytical Services Inc. (Maugansville, MD) for analysis of $\mathrm{DM}\left(135^{\circ} \mathrm{C}\right.$; AOAC International, 2000: method 930.15), ash $\left(535^{\circ} \mathrm{C}\right.$; AOAC International, 2000: method 942.05), ADF (AOAC International, 2000: method 973.18), NDF with heat-stable $\alpha$-amylase and sodium sulfate (Van Soest et al., 1991), and CP $(\mathrm{N} \times 6.25 ;$ AOAC International, 2000: method 990.03; Leco FP-528 Nitrogen Analyzer, Leco, St. Joseph, MI). Nonfiber carbohydrate content was also calculated, as $100-(\% \mathrm{CP}+\% \mathrm{NDF}+\%$ fat $+\%$ ash $)(\mathrm{NRC}$, 2001). Nutrient composition of the feed rations for each participating farm are summarized in Table 3.

\section{Statistical Analyses}

Cows that had aborted $(\mathrm{n}=2)$, were sold $(\mathrm{n}=2)$, or were diagnosed with SCK before calving $(\mathrm{n}=3)$ were not included in the statistical analysis. Cows that were sold $(\mathrm{n}=22)$ or died $(\mathrm{n}=1)$ during the postcalving period with behavioral and health measurements recorded until the day they left the herd were included in the analysis. The final data set included 339 cows (107 primiparous and 232 multiparous) categorized as HLT ( $=139), \operatorname{HLT}+(\mathrm{n}=50)$, HYK $(\mathrm{n}=97)$, and $\mathrm{HYK}+(\mathrm{n}=53)$.

For all further analyses described, comparisons were made between HLT and HYK cows and HLT and HYK+ cows, respectively; HLT + cows were not considered in the analysis. Statistical analyses were performed with SAS (version 9.4, 2013; SAS Institute Inc., Cary, NC) using cow within farm $(\mathrm{n}=289)$ as the experimental unit. Daily rumination times $(\mathrm{min} / \mathrm{d})$ were summarized by cow and week (14 to $8 \mathrm{~d}$ before calving, 7 to $1 \mathrm{~d}$ before calving, 1 to 7 DIM, 8 to 14 DIM, 15 to 21
DIM, and 22 to 28 DIM), such that these data aligned with the once-weekly testing of SCK. These data were analyzed in a general linear mixed model (MIXED procedure in SAS), treating week as a repeated measure. The model for rumination time included the random effects of farm and cow within farm (accounting for repeated measures) and the fixed effects of health status, parity, and week, the interactions of health status with parity and health status with week, as well as the 3 -way interaction of health status, parity, and week. The covariance structure was heterogeneous compound symmetry, selected by best fit according to Schwarz's Bayesian information criterion. A 3-way interaction was found between health status, parity, and week $(P$ $<0.01$ ); thus, data from first-lactation (primiparous) and multiparous cows were analyzed separately. These separate models included the fixed effects of health status, week and the interaction between health status and week, with farm and cow within farm included as random effects. Differences in rumination time between health categories and weeks were compared using the least squares means procedure with the PDIFF option. Significance was declared at $P \leq 0.05$, and tendencies were reported if $0.05<P \leq 0.10$.

In the analysis of the effect of health status on rumination time, as described above, differences were only found between health categories for multiparous cows. Thus, multivariable logistic regression was only performed on data from multiparous cows and not on primiparous cows. This analysis was performed using the GLIMMIX procedure (distribution $=$ binomial and link $=$ logit) in SAS to model to effects of rumination time and other cow-level factors on the presence or absence of SCK. This was done using 2 models: one model com- 
pared HLT and HYK cows, whereas the other compared HLT and HYK+ cows. Parity and precalving BCS were both treated as categorical variables. Multiparous cows (HLT, HYK, and HYK+) were characterized as second lactation $(2 ; \mathrm{n}=99)$ or third lactation and greater $(3+; \mathrm{n}=103)$. Body condition score precalving was categorized into 3 groups: underconditioned, BCS $<3$; normal, $\mathrm{BCS}=3$ to 3.5 ; overconditioned, $\mathrm{BCS}>3.5$. Parity, precalving BCS category, change in BCS over the transition period (BCS at enrollment - BCS at time of removal from study), length of dry period, milk yield from the previous lactation, as well as rumination time and stall stocking density during the weeks before the mean day of diagnosis (wk $-2,-1$, and +1 relative to calving), were all assessed for an association with presence or absence of HYK and HYK+ using univariable logistic regression models. Variables with $P \leq 0.25$ were then used to construct a multivariable logistic regression model. The CORR procedure in SAS was used to check for correlations between the explanatory variables (parity, BCS precalving, change in BCS, dry period length, 305-d milk yield, stall stocking density, and rumination time) included in the multivariable model. If 2 variables were highly correlated $(\mathrm{r}>0.8)$, the variable with the lowest $P$-value and most biological relevance was retained for the multivariable model. Manual backward elimination of variables with $P>$ 0.10 was used to create the final models. Using the final resultant models, all biologically plausible 2 -way interactions were examined and retained if $P \leq 0.10$. Only those variables retained in the final multivariable models are presented.

\section{RESULTS}

A descriptive summary of cow-level variables, characterized by herd, is given in Table 4 . Of the 339 cows, $139(41 \%)$ did not have SCK or any other health problems. Table 5 describes the prevalence of ketosis. In total, 150 cows had ketosis (44\%) and of these, 53 were treated for at least one other health problem $(16 \%$ of all cows). The incidence risks for diseases other than SCK are described in Table 5, with metritis being the most common treated illness, followed by retained placenta, mastitis, milk fever, foot problems, and displaced abomasum.

Figure 1 illustrates how rumination time evolved across the transition period for both the primiparous and multiparous cows. Among cows in their first lactation, from $2 \mathrm{wk}$ before calving until 4 wk after calving, no differences in rumination time $(P=0.5)$ were observed among HLT, HYK, and HYK+ cows (Table $6)$. Rumination time in primiparous cows varied by

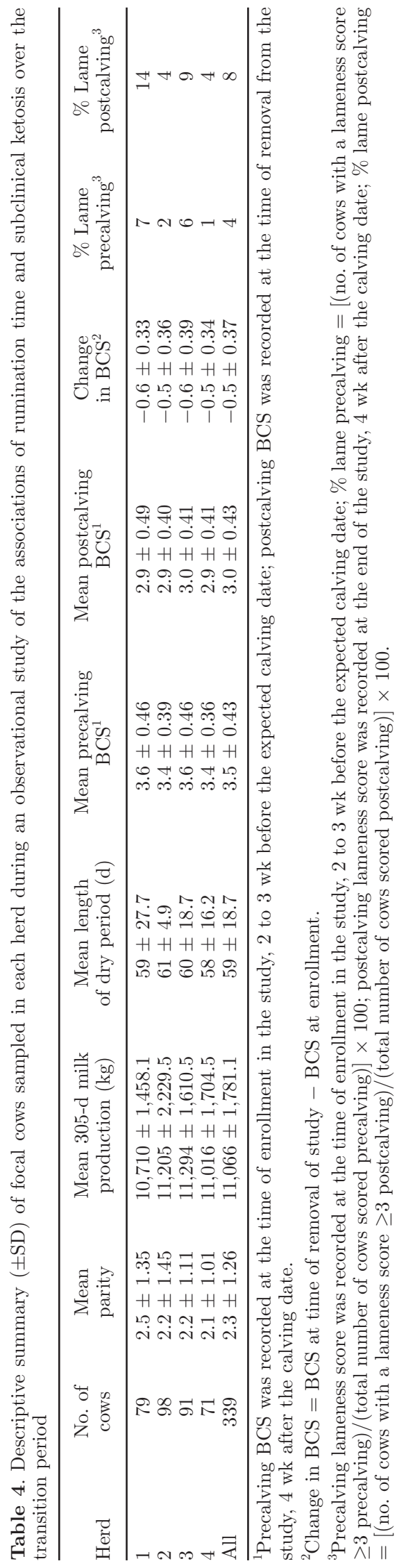

Journal of Dairy Science Vol. 99 No. 7, 2016 


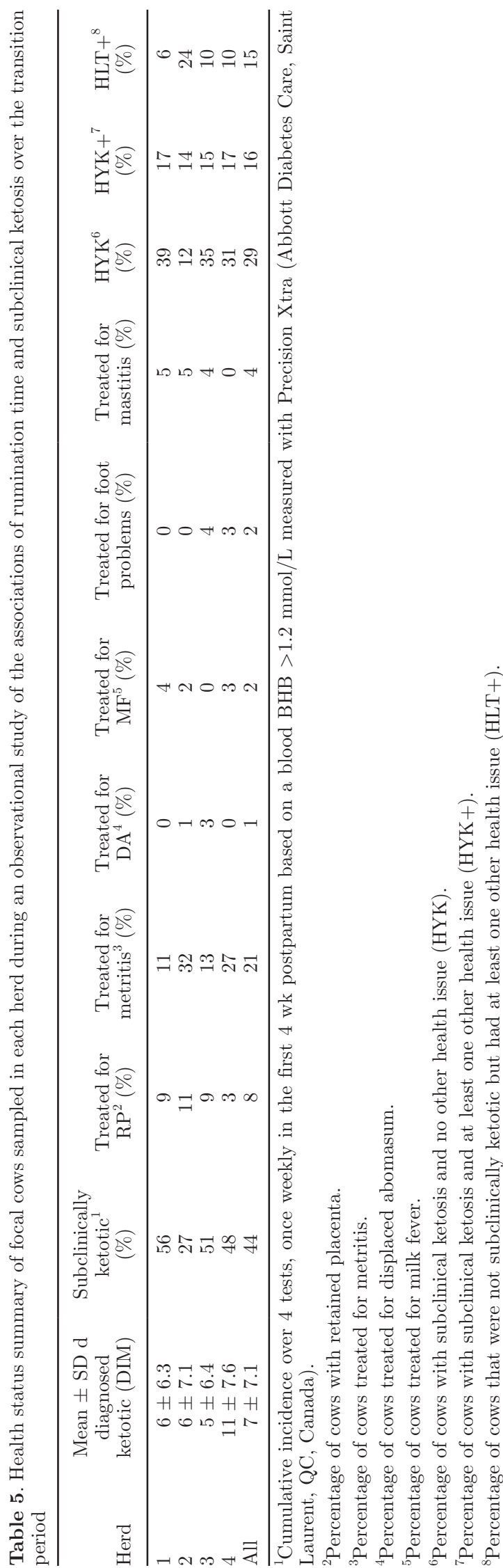

week $(P<0.001)$. Primiparous cows ruminated less in wk -1 than in wk $-2(P=0.001)$, and rumination time increased from wk +1 to wk $+2(P<0.001)$ and decreased from wk +3 to wk $+4(P=0.04)$. An interaction for rumination time was found between parity and week $(P=0.05)$. There was no difference in rumination during wk -1 and +1 ; however, primiparous cows tended to ruminate less in wk $+2(26 \pm 15.9 \mathrm{~min} / \mathrm{d}$ less, $P=0.06)$. During wk +3 and +4 , primiparous cows ruminated less $(38 \pm 15.9 \mathrm{~min} / \mathrm{d}, P=0.02$; and $51 \pm 17.8 \mathrm{~min} / \mathrm{d}, P<0.01$; respectively) than multiparous cows.

For multiparous cows, an interaction was found between health status and week $(P=0.01$; Table 6$)$. There was an effect of time $(P<0.001)$ across all health statuses: rumination time decreased in wk -1 compared with wk -2 but increased each week from wk -1 to +2 . Multiparous HYK cows tended to ruminate less than multiparous HLT cows during wk -1 and wk +1 (Table $6)$. The largest differences in rumination time between multiparous HLT and HYK + cows were seen during wk $-1,+1$, and +2 . Figure 2 illustrates how the daily rumination time evolved across the transition period for HLT, HYK, and HYK+ multiparous cows.

Table 7 shows the unconditional associations of the multivariable model. Increased odds of SCK with no other recorded health problems (HYK) were associated with higher parity $(3+$ compared with second-lactation cows), greater milk yield during the previous lactation, longer dry period, cows being in the overconditioned category precalving, greater stall stocking density during wk $-2,-1$, and +1 , and greater loss in BCS over the transition period. Decreased odds of SCK with no other health problems, relative to HLT, were associated with a greater stall stocking density during wk +1 and greater rumination time during wk -1 . Four of these variables were retained in the final multivariable model (Table 8). Greater rumination time during the week before calving was associated with decreased odds of HYK, whereas greater milk yield in the previous lactation, greater loss of BCS over the transition period, and greater stall stocking density in the week before calving were all associated with increased odds of HYK relative to HLT.

Unconditional associations of the independent variables for HLT versus HYK+ cows are shown in Table 9. There were increased odds of developing SCK combined with another health problem with higher parity (3+ compared with second-lactation cows), greater milk yield during the previous lactation, longer dry period, higher BCS precalving, cows being in the overconditioned category precalving, greater change in BCS over the transition period, and greater stall stocking density during wk -2 and -1 . The odds of SCK with 
Table 6. Least squares means $( \pm \mathrm{SE})$ for rumination time $(\mathrm{min} / \mathrm{d})$ for healthy cows without subclinical ketosis or other recorded illnesses (HLT), subclinically ketotic cows with no other health problems (HYK), and subclinically ketotic cows with other health problems (HYK+) during each week of the study period

\begin{tabular}{|c|c|c|c|c|c|c|c|}
\hline \multirow[b]{2}{*}{ Health status } & \multirow[b]{2}{*}{ No. } & \multicolumn{6}{|c|}{ Period (relative to calving) } \\
\hline & & wk -2 & wk -1 & $\mathrm{wk}+1$ & $\mathrm{wk}+2$ & $\mathrm{wk}+3$ & $\mathrm{wk}+4$ \\
\hline \multicolumn{8}{|l|}{ Primiparous } \\
\hline HLT & 52 & $407 \pm 13.7$ & $376 \pm 11.8$ & $375 \pm 10.6$ & $439 \pm 12.5$ & $439 \pm 14.2$ & $421 \pm 17.0$ \\
\hline HYK & 21 & $421 \pm 25.2$ & $374 \pm 21.3$ & $393 \pm 16.7$ & $465 \pm 19.7$ & $460 \pm 22.3$ & $434 \pm 26.7$ \\
\hline HYK+ & 14 & $380 \pm 25.8$ & $342 \pm 22.4$ & $366 \pm 20.5$ & $451 \pm 24.1$ & $428 \pm 27.3$ & $395 \pm 32.9$ \\
\hline \multicolumn{8}{|l|}{ Multiparous } \\
\hline HYK+ & 39 & $405 \pm 16.6$ & $354 \pm 16.0^{* *}$ & $356 \pm 15.2^{* * *}$ & $444 \pm 17.7^{* *}$ & $463 \pm 20.0 \dagger$ & $468 \pm 21.7$ \\
\hline
\end{tabular}

another health problem $(\mathrm{HYK}+)$ with greater rumination time were decreased during wk -1 and +1 . Four of these variables were retained in the final multivariable model (Table 10). Greater rumination time during the week after calving was associated with decreased risk of $\mathrm{HYK}+$, whereas being in the third parity or higher, having a longer dry period, and experiencing greater stall stocking density in the week before calving were all associated with increased risk of $\mathrm{HYK}+$ relative to HLT.

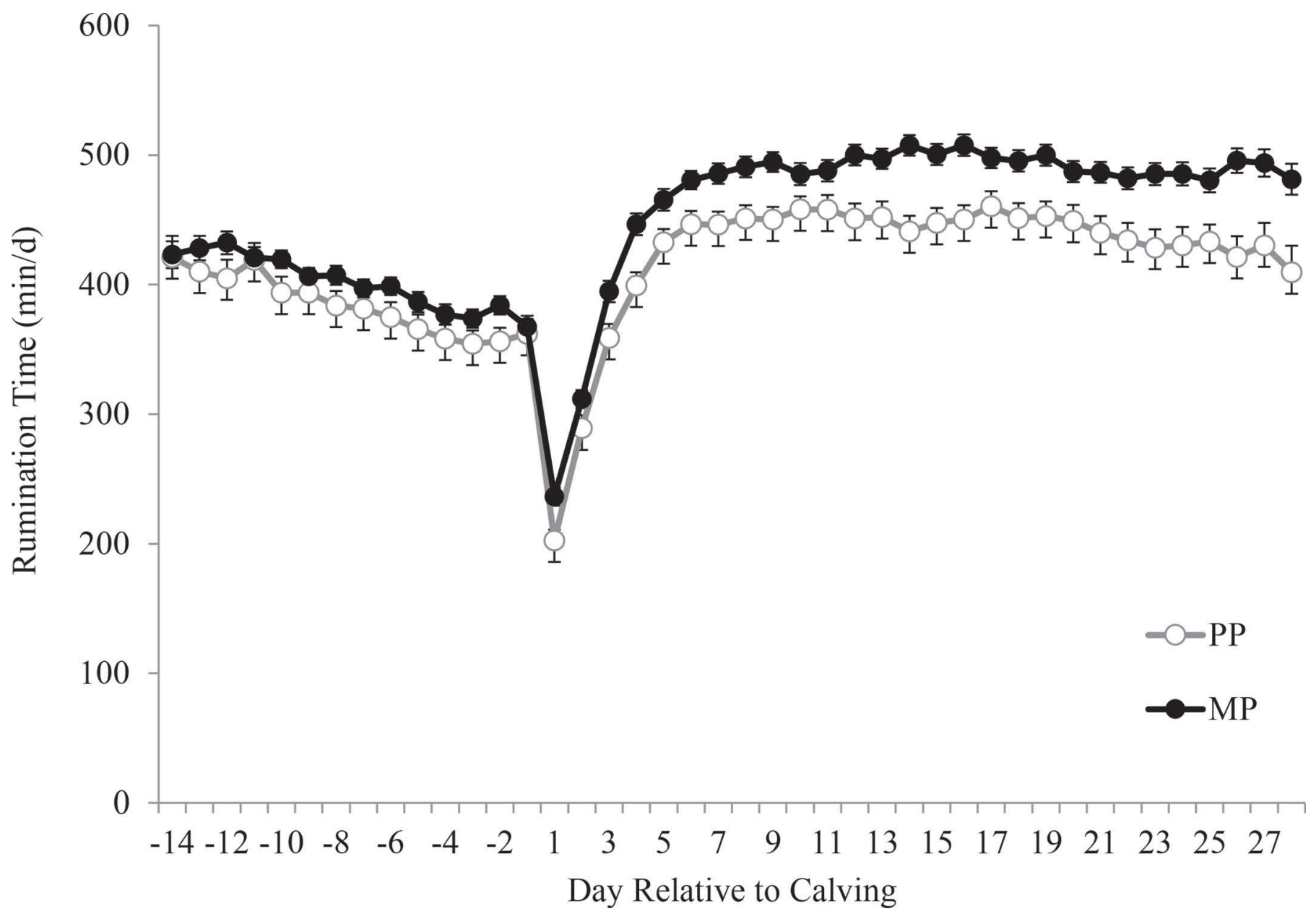

Figure 1. Daily rumination time (mean $\pm \mathrm{SE}$; min/d) over the transition period ( -14 to $28 \mathrm{~d}$ ) for primiparous $(\mathrm{PP}, \mathrm{n}=87)$ and multiparous $(\mathrm{MP}, \mathrm{n}=202)$ cows. 


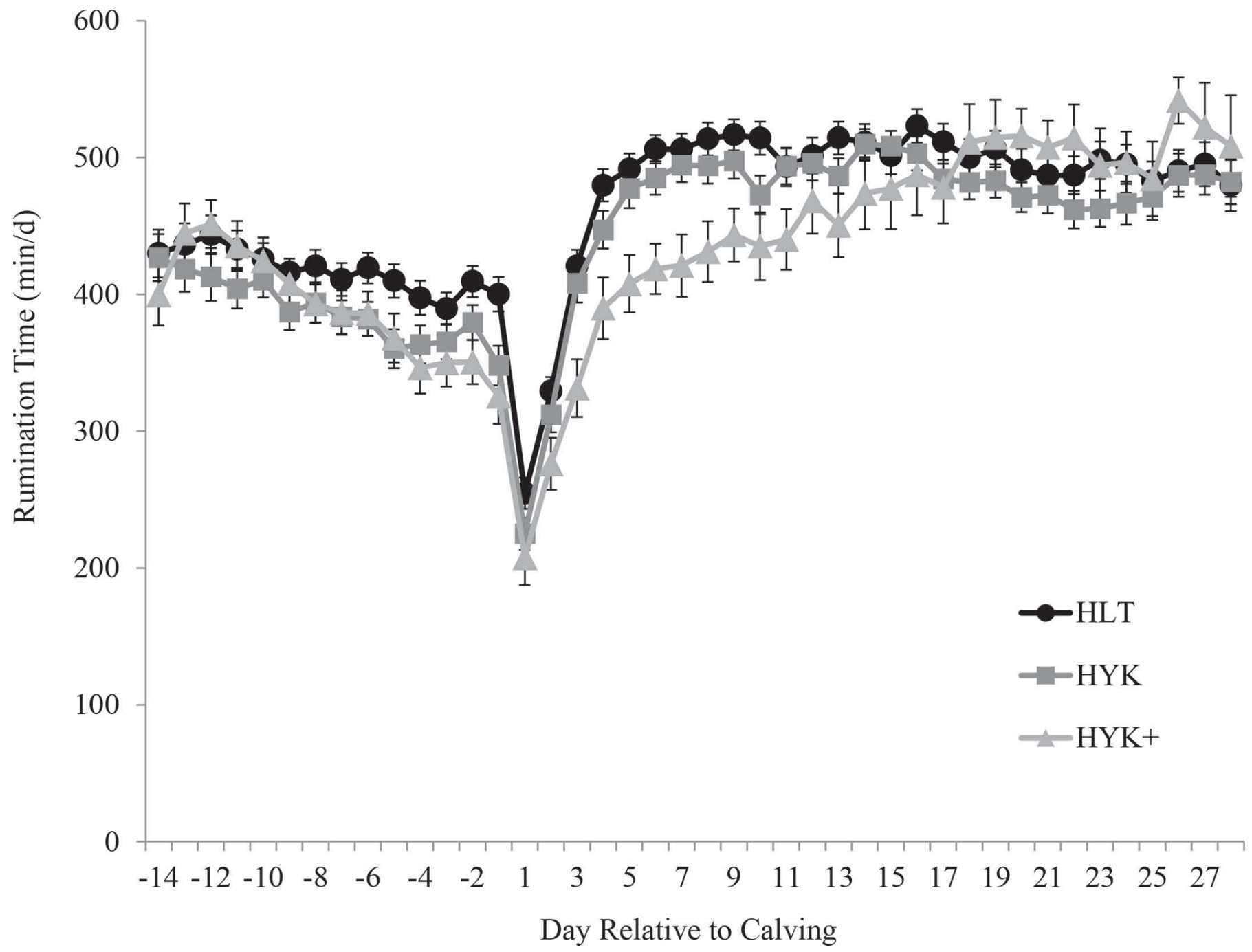

Figure 2. Daily rumination time (mean $\pm \mathrm{SE}$; min/d) over the transition period ( -14 to $28 \mathrm{~d}$ ) for healthy multiparous cows with no other recorded illnesses (HLT; $\mathrm{n}=87$ ), subclinically ketotic multiparous cows with no other health problems $(\mathrm{HYK} ; \mathrm{n}=76)$ and subclinically ketotic multiparous cows with other health problems $(\mathrm{HYK}+; \mathrm{n}=39)$.

\section{DISCUSSION}

In this study, we characterized the changes in rumination behavior across the transition period. Both primiparous and multiparous cows experienced a reduction in rumination time from wk -2 to -1 prepartum, which, as suggested by Liboreiro et al. (2015), may be associated with the common reduction in DMI leading up to calving. Similarly, the rumination time of primiparous and multiparous cows began to increase from wk +1 to +2 , again potentially reflective of changes in DMI. Dry matter intake typically decreases as the cow approaches calving and begins to increase rapidly after calving (Grant and Albright, 1995). Although an association of rumination time and DMI is not consistently reported in the literature, there are examples of these being positively associated. Cows have been found to spend more time ruminating about $4 \mathrm{~h}$ after periods of high feed intake (Schirmann et al., 2012); however, there was no correlation between periods of DMI and rumination time in that study, possibly due to large variations of these variables both between and within cows. Clément et al. (2014) recently found that rumination time was a significant, but small, contributor in a DMI prediction model. These researchers suggested that the variability of rumination time within weeks and cows makes it difficult to predict DMI from rumination time.

Rumination time is more consistently associated with dietary NDF intake (Welch and Smith, 1970; Beauche- 
Table 7. Unconditional estimates for factors associated with the incidence of subclinical ketosis with no recorded clinical disease (HYK; $\mathrm{n}=76$ ) relative to healthy animals (HLT; $\mathrm{n}=87$ ), in multiparous cows

\begin{tabular}{|c|c|c|c|}
\hline Variable & $\begin{array}{l}\text { Percentage or } \\
\text { mean }( \pm \mathrm{SD})^{1}\end{array}$ & $\begin{array}{l}\text { Odds ratio } \\
(95 \% \mathrm{CI})^{2}\end{array}$ & $P$-value \\
\hline Parity (\%) & & & 0.002 \\
\hline 2 & 51 & Referent & - \\
\hline $3+$ & 49 & $2.9(1.49$ to 5.65$)$ & - \\
\hline Previous 305-d milk yield (kg) & $11,060(1,785.0)$ & $1.2(0.88$ to 1.73$)$ & 0.21 \\
\hline Length of dry period (d) & $59(19.0)$ & $1.7(1.00$ to 2.86$)$ & 0.049 \\
\hline BCS precalving & $3.4(0.44)$ & $1.3(0.96$ to 1.88$)$ & 0.083 \\
\hline BCS category precalving ${ }^{3}(\%)$ & & & 0.17 \\
\hline Normal & 70 & $0.9(0.20$ to 4.32$)$ & - \\
\hline Underconditioned & 5 & Referent & - \\
\hline Overconditioned & 25 & $2.1(0.95$ to 4.54$)$ & - \\
\hline Change in $\mathrm{BCS}^{4}$ & $0.5(0.37)$ & $1.6(1.13$ to 2.29$)$ & 0.0081 \\
\hline \multicolumn{4}{|l|}{ Stall stocking density ${ }^{5}(\%)$} \\
\hline wk -2 & $84(23.6)$ & $1.6(1.15$ to 2.29$)$ & 0.0063 \\
\hline wk -1 & $79(24.5)$ & $1.6(1.15$ to 2.16$)$ & 0.0053 \\
\hline wk +1 & $81(14.8)$ & $0.6(0.36$ to 0.87$)$ & 0.011 \\
\hline \multicolumn{4}{|l|}{ Rumination time (min/d) } \\
\hline wk -1 & $382(85.6)$ & $0.7(0.46$ to 0.97$)$ & 0.036 \\
\hline
\end{tabular}

${ }^{1}$ Proportion of animals for categorical variables or mean and standard deviation for continuous variables.

${ }^{2}$ Odds ratio and $95 \%$ CI for 1 SD increase in the variable presented.

${ }^{3}$ Cows were placed into 1 of 3 categories based on their body condition score precalving: normal (BCS 3-3.5), underconditioned (BCS <3.0), overconditioned (BCS >3.5).

${ }^{4}$ Change in BCS $=$ BCS at enrollment - BCS at time of removal of study.

${ }^{5}$ Stocking density (ST) for freestall pens was calculated as ST $=$ [no. of cows in pen]/[no. of stalls]. Bedded packs were calculated as $\mathrm{ST}=[$ no. of cows in bedded pack $] /\left\{\left(\right.\right.$ dimensions, $\left.\mathrm{m}^{2}\right) /[$ recommended space allowance, $11 \mathrm{~m}^{2}$; Nordlund (2009)]\}.

min et al., 1994) and particle size (Kononoff et al., 2003; Beauchemin and Yang, 2005). Rumination time increases as particle size increases (Beauchemin et al., 1994); unfortunately, we did not measure particle size in this study, which may have provided greater insight into differences in rumination times observed. The NDF content in the fresh cow diets ranged from 28 to $32 \%$ of DM across the 4 commercial dairy farms in this study. Dado and Allen (1995) showed that rumination time in early lactation dairy cows, measured using a halter that recorded jaw movements, increased from 380 to $500 \mathrm{~min} / \mathrm{d}$ when the NDF content of the ration was increased from 25 to $35 \%$. Rumination time averaged 418 and $481 \mathrm{~min} / \mathrm{d}$ for healthy; lactating primiparous and multiparous cows respectively, which is comparable to that reported by Dado and Allen (1995). These averages are also within the reported range of 340 to $540 \mathrm{~min} / \mathrm{d}$ for lactating cows (using jaw movement re-

Table 8. Final logistic regression model for factors associated with the incidence of subclinical ketosis with no other health issues (HYK; $\mathrm{n}=76$ ) relative to healthy animals (HLT; $\mathrm{n}=87$ ), in multiparous cows

\begin{tabular}{|c|c|c|c|c|}
\hline Variable & Coefficient & SE & $\begin{array}{l}\text { Odds ratio } \\
(95 \% \mathrm{CI})^{1}\end{array}$ & $P$-value \\
\hline Intercept & -3.27 & 2.042 & & 0.21 \\
\hline Previous 305-d milk yield (kg) & 0.00024 & 0.000133 & $1.5(0.96$ to 2.47$)$ & 0.073 \\
\hline Change in $\mathrm{BCS}^{2}$ & 1.68 & 0.622 & $1.9(1.18$ to 2.94$)$ & 0.0083 \\
\hline $\begin{array}{l}\text { Stall stocking density }{ }^{3}(\%) \\
\text { wk }-1\end{array}$ & 0.02 & 0.009 & $1.7(1.10$ to 2.58$)$ & 0.018 \\
\hline $\begin{array}{l}\text { Rumination time }(\min / \mathrm{d}) \\
\text { wk }-1\end{array}$ & -0.01 & 0.003 & $0.6(0.38$ to 0.97$)$ & 0.037 \\
\hline
\end{tabular}

${ }^{1}$ Adjusted odds ratio and 95\% CI for 1 SD increase in each variable in the model. The mean \pm SD for each variable are as follows: $11,060 \pm 1,785.0 \mathrm{~kg}$, 305-d milk yield; $0.5 \pm 0.37$, change in BCS; $80 \pm 24.8 \%$, stall stocking density (wk -1$) ; 382 \pm 85.6 \mathrm{~min} / \mathrm{d}$, rumination time (wk -1$)$.

${ }^{2}$ Change in BCS $=$ BCS at enrollment - BCS at time of removal of study.

${ }^{3}$ Stocking density (ST) for freestall pens was calculated as ST $=$ [no. of cows in pen]/[no. of stalls]. Bedded packs were calculated as $\mathrm{ST}=[$ no. of cows in bedded pack $] /\left\{\right.$ (dimensions, $\left.\mathrm{m}^{2}\right) /[$ recommended space allowance, $11 \mathrm{~m}^{2}$; Nordlund (2009)]\}. 
Table 9. Unconditional estimates for factors associated with the incidence of subclinical ketosis with other health problems $(\mathrm{HYK}+; \mathrm{n}=39)$ relative to healthy animals (HLT; $\mathrm{n}=87)$, in multiparous cows

\begin{tabular}{|c|c|c|c|}
\hline Variable & $\begin{array}{l}\text { Percentage or } \\
\text { mean }( \pm S D)^{1}\end{array}$ & $\begin{array}{l}\text { Odds ratio } \\
(95 \% \mathrm{CI})^{2}\end{array}$ & $P$-value \\
\hline \multicolumn{3}{|l|}{ Parity (\%) } & $<0.001$ \\
\hline 2 & 51 & Referent & - \\
\hline $3+$ & 49 & $5.5(2.35$ to 12.92$)$ & - \\
\hline Previous 305-d milk yield ( $\mathrm{kg}$ ) & $11,061(1,785.0)$ & $1.5(1.02$ to 2.18$)$ & 0.039 \\
\hline Length of dry period (d) & $59(19.0)$ & $1.9(1.05$ to 3.27$)$ & 0.034 \\
\hline BCS precalving & $3.4(0.44)$ & $1.3(0.90$ to 1.94$)$ & 0.15 \\
\hline \multicolumn{3}{|l|}{ BCS category precalving ${ }^{3}(\%)$} & 0.14 \\
\hline Normal & 70 & Referent & - \\
\hline Underconditioned & 5 & $1.1(0.20$ to 6.25$)$ & - \\
\hline Overconditioned & 25 & $2.4(1.00$ to 5.87$)$ & - \\
\hline Change in $\mathrm{BCS}^{4}$ & $0.5(0.37)$ & $1.5(0.97$ to 2.24$)$ & 0.068 \\
\hline \multicolumn{4}{|l|}{ Stall stocking density ${ }^{5}(\%)$} \\
\hline wk -2 & $84(23.6)$ & $1.4(0.97$ to 2.13$)$ & 0.071 \\
\hline wk -1 & $79(24.5)$ & $1.9(1.22$ to 2.92$)$ & 0.0048 \\
\hline \multicolumn{4}{|l|}{ Rumination time $(\mathrm{min} / \mathrm{d})$} \\
\hline wk -1 & $382(85.6)$ & $0.6(0.40$ to 0.92$)$ & 0.019 \\
\hline wk +1 & $407(87.4)$ & $0.4(0.25$ to 0.63$)$ & $<0.001$ \\
\hline
\end{tabular}

${ }^{1}$ Proportion of observations for categorical variables or mean and standard deviation for continuous variables. ${ }^{2}$ Odds ratio and $95 \%$ CI for $1 \mathrm{SD}$ in variable presented.

${ }^{3}$ Cows were placed into 1 of 3 categories based on their BCS precalving: normal (BCS 3-3.5), underconditioned (BCS $<3.0$ ), or overconditioned (BCS >3.5).

${ }^{4}$ Change in BCS $=$ BCS at enrollment - BCS at time of removal of study.

${ }^{5}$ Stocking density (ST) for freestall pens was calculated as ST $=$ [no. of cows in pen $] /[$ no. of stalls $]$. Bedded packs were calculated as $\mathrm{ST}=[$ no. of cows in bedded pack $] /\left\{\left(\right.\right.$ dimensions, $\left.\mathrm{m}^{2}\right) /[$ recommended space allowance, $11 \mathrm{~m}^{2}$; Nordlund (2009)]\}.

corders) found in the literature (Kononoff et al., 2003; Beauchemin and Yang, 2005; Yang and Beauchemin, 2006).

Even though the close-up dry cow diets were greater in NDF than the fresh cow diets in the study herds, the expected changes in DMI across this period would result in much greater intake of total NDF in the postpartum period. Thus, it is possible that the changes in rumination time reflected the changes in DMI across this period. More research on the association of DMI and rumination during the transition period is needed, particularly accounting for changes in physical and chemical composition of diets from pre- to postcalving.

In this study, primiparous cows ruminated less than multiparous cows during wk +3 and +4 after calving. Maekawa et al. (2002) found that primiparous cows ruminated $52 \mathrm{~min} / \mathrm{d}$ less than multiparous cows in mid lactation, using visual observation; this difference was attributed to the greater DMI of multiparous cows, which also had greater BW and higher milk yields than

Table 10. Final logistic regression model for factors associated with the incidence of subclinical ketosis with other health problems (HYK + ; $=39$ ) relative to healthy animals (HLT; $\mathrm{n}=87$ ), in multiparous cows

\begin{tabular}{|c|c|c|c|c|}
\hline Variable & Coefficient & $\mathrm{SE}$ & $\begin{array}{l}\text { Odds ratio } \\
(95 \% \mathrm{CI})^{1}\end{array}$ & $P$-value \\
\hline Intercept & -3.67 & 2.750 & - & 0.27 \\
\hline Parity & & & & $<0.001$ \\
\hline 2 & Referent & - & - & - \\
\hline $3+$ & 2.09 & 0.580 & $8.1(2.55$ to 25.43$)$ & - \\
\hline Length of dry period (d) & 0.06 & 0.032 & $2.9(0.87$ to 9.56$)$ & 0.083 \\
\hline $\begin{array}{l}\text { Stall stocking density }{ }^{2}(\%) \\
\text { wk }-1\end{array}$ & 0.02 & 0.012 & $1.8(1.01$ to 3.27$)$ & 0.046 \\
\hline $\begin{array}{l}\text { Rumination time }(\mathrm{min} / \mathrm{d}) \\
\mathrm{wk}+1\end{array}$ & -0.01 & 0.003 & $0.5(0.27$ to 0.80$)$ & 0.0063 \\
\hline
\end{tabular}

${ }^{1}$ Adjusted odds ratio and 95\% CI for 1 SD increase in each variable in the model. The mean \pm SD for each variable are as follows: $59 \pm 19.0 \mathrm{~d}$, length of dry period; $80 \pm 24.8 \%$, stall stocking density (wk -1 ); $407 \pm$ $87.4 \mathrm{~min} / \mathrm{d}$, rumination time $(\mathrm{wk}+1)$.

${ }^{2}$ Stocking density (ST) for freestall pens was calculated as ST $=$ [no. of cows in pen]/[no. of stalls]. Bedded packs were calculated as $\mathrm{ST}=[$ no. of cows in bedded pack $] /\left\{\left(\right.\right.$ dimensions, $\left.\mathrm{m}^{2}\right) /[$ recommended space allowance, $11 \mathrm{~m}^{2}$; Nordlund (2009)]\}. 
primiparous cows. Beauchemin and Rode (1994) monitored rumination time with a strain gauge that assessed jaw movement; they observed lactating multiparous cows to have a longer daily rumination time; primiparous and multiparous cows regurgitated a similar number of boluses; however, multiparous cows spent more time chewing each bolus. Soriani et al. (2012) suggested that primiparous cows suffer more from the stress of environmental changes at the initiation of lactation, and thus show a slower increase in rumination time after calving compared with multiparous cows. Other researchers have measured rumination time over the transition period and reported no difference between primiparous and multiparous cows (Soriani et al., 2013; Calamari et al., 2014; Liboreiro et al., 2015); unfortunately, no discussion of this lack of difference was presented in those studies.

Rumination time for HLT multiparous cows during the dry period $(408 \mathrm{~min} / \mathrm{d})$ is within the range of 400 to $450 \mathrm{~min} / \mathrm{d}$ reported by Adin et al. (2009) for close-up cows fed a similar diet. Soriani et al. (2012) found that daily rumination time averaged $522 \mathrm{~min} / \mathrm{d}$ during $\mathrm{d}$ -10 to -2 precalving, which was higher than what was observed in this study for HLT cows during the same period. This difference in rumination time is probably due to the greater amount of NDF in their dry cow diet, which was $56 \%$ of DM (Soriani et al., 2012), compared with an average of $37 \%$ of DM in this study.

No difference in rumination time was found between health categories for primiparous cows (Table 6). This may be due to a low sample size among the subgroups with SCK (HLT, $\mathrm{n}=52 ; \mathrm{HYK}, \mathrm{n}=21 ; \mathrm{HYK}+, \mathrm{n}=14$ ). The initial sample size calculation was based on comparing only primiparous cows with SCK versus without SCK. With a larger sample size and greater number of HYK and HYK + cows, it may have been possible to detect differences between healthy primiparous cows and primiparous cows with SCK; we recommend further research to address this. In our study, multiparous cows with only SCK tended to ruminate less during the week before and the week after calving. Recently, Liboreiro et al. (2015) sampled both primiparous and multiparous cows and did not find an association between SCK and precalving or postcalving daily rumination time. However, in that study, cows diagnosed with SCK had reduced daily rumination time from d 0 to 8 postcalving, and tended to have reduced daily rumination time on d 11 postcalving compared with cows without SCK. It is unclear whether the subjects in Liboreiro et al. (2015) were only diagnosed with SCK or could have had multiple health disorders, which may have had a further effect on rumination time, as demonstrated in the present study.
Lower rumination times were observed in multiparous HYK + cows during wk $-1,+1$, and +2 compared with HLT cows. Soriani et al. (2012) categorized cows into 3 groups based on rumination time before calving: longer rumination time, middle rumination time, and shorter rumination time. Cows in the shorter rumination group showed a higher incidence of clinical disease (including mastitis, lameness, ketosis, and DA) and these cows had a decreased rumination time after calving, similar to what was seen in HYK+ cows in the current study. This also agrees with the observations made by Calamari et al. (2014), who found that $90 \%$ of cows in the low rumination group postcalving had a clinical health problem, compared with $45 \%$ of cows categorized in the high rumination group. Liboreiro et al. (2015) recently reported similar effects of postpartum illness on rumination time; those researchers found that cows with milk fever on the day of calving and cows diagnosed with metritis between d 2 and 9 postpartum had reduced rumination time.

In the present study, the odds of developing SCK and another clinical disease were 1.2 times greater for every $20 \mathrm{~min} / \mathrm{d}$ decrease in rumination time during the week after calving. Although there was also a difference in rumination during the week before calving, the depression in rumination time was much greater in the week after calving, possibly because of the combined effect of multiple transition disorders occurring postcalving, some of which may have preceded the diagnosis of SCK. In this study, SCK was only diagnosed once weekly, which was a limitation of the study. If cows were ketotic on the day of diagnosis, we did not know whether that was the first day of SCK or if the cow had been ketotic for multiple days. McArt et al. (2012) found the median time to resolution of SCK without treatment was $5 \mathrm{~d}$; by testing only once per week in the current study, the onset and recovery of SCK may have occurred between sample days, causing the misclassification of subclinically ketotic cows as healthy cows. This type of misclassification may have created a bias toward the null during the analysis, meaning the differences in rumination time between health categories may have been underestimated. This also limited our ability to fully understand how rumination changes directly before and after the onset of SCK. Future studies monitoring this association should monitor SCK more frequently to understand the detailed changes in rumination around the onset of illness.

When comparing HYK with HLT cows, we found that for every $20 \mathrm{~min} / \mathrm{d}$ decrease in rumination time during the week before calving, the odds of becoming HYK postcalving increased 1.1-fold. Low DMI and reduced feeding time are considered important risk fac- 
tors for SCK. Studies by González et al. (2008) and Goldhawk et al. (2009) observed a 10-kg reduction in fresh feed intake per day and a $3-\mathrm{kg}$ reduction in daily DMI, respectively, during the week before being diagnosed ketotic. Shorter rumination times in the current study may be indicative of low DMI in the prepartum period (Clément et al., 2014); however, many cow-level and management-related factors vary between farms and have a great effect on rumination time.

The cumulative incidence of SCK across 25 Ontario farms ranged from 8 to $80 \%$ during the first 9 wk postpartum, with a mean of $43 \%$ of cows that experienced SCK (Duffield, 2000). McArt et al. (2012) also found a $43 \%$ cumulative incidence of ketosis with thrice weekly testing between 3 and 16 DIM, with the peak incidence of ketosis occurring at 5 DIM. These estimates are in line with the $44 \%$ cumulative incidence of SCK within the first 4 wk postpartum observed in the present study.

There is much evidence in the literature supporting the notion that severe NEB in the transition period increases the risk for postpartum diseases such as retained placenta, milk fever, metritis, mastitis, displaced abomasum, and SCK (Dohoo et al., 1983; Duffield et al., 2009; LeBlanc, 2010). LeBlanc (2010) estimated that 30 to $50 \%$ of cows experience some form of health problem around the time of calving. Similar to that, in the current study, $35 \%$ of cows diagnosed with SCK had at least one other recorded health problem during the first 4 wk postpartum.

It is apparent that SCK and other postpartum diseases are common in commercial dairy herds, but the causes are not always apparent as there are numerous factors, including parity, breed, BCS, milk yield, dry cow nutrition, and management factors that have been associated with risk of both SCK and clinical ketosis (Andersson, 1988; Duffield, 2000). Increasing parity is a known risk factor for SCK (Suthar et al., 2013; Berge and Vertenten, 2014; Vanholder et al., 2015), which was also found in the present study; for example, the odds of SCK in HYK + cows were 8 times higher in $3+$ lactation cows compared with HLT cows in their second lactation. Cows with higher milk production have higher nutrient demands, putting them at a higher risk of developing SCK (Bauman and Currie, 1980; Gröhn et al., 1995; Fleischer et al., 2001), which is why cows in the present study with greater 305-d milk yield in the previous lactation were at increased odds for having SCK with no other health issues. Vanholder et al. (2015) found that cows in both the moderate $(3.5 \leq \mathrm{BCS} \leq 3.75)$ and fat BCS categories (BCS $\geq 4$ ) had an increased risk of SCK compared with cows in the thin category $(\mathrm{BCS} \leq 3)$. Cows with greater BCS precalving have a greater decrease in DMI before calving (Hayirli et al., 2002), which is a major contributing factor for develop- ing SCK postpartum (Goldhawk et al., 2009). Cows in a state of NEB will deplete fat stores to compensate for the high energy demands of lactation (Goldhawk et al., 2009). Therefore, it is not surprising that in our study, a greater loss of BCS over the transition period was associated with increased risk of experiencing SCK in cows with no other health problems.

In the present study, each extra 5 d dry above the mean (59 d) increased the odds of developing SCK combined with another postpartum health disorder 1.3-fold. Vanholder et al. (2015) similarly observed this positive association between the length of the dry period and SCK. It is possible that cows with a longer dry period become overconditioned. Cows consuming the close-up ration longer than the recommended $3 \mathrm{wk}$ have been shown to have increased BCS and risk of metritis postpartum (Mashek and Beede, 2001). We could also hypothesize that these cows with long dry periods became pregnant later in lactation and were already overconditioned before dry off.

Increasing stall stocking density by $5 \%$ during the week before calving was found to increase the risk of ketosis by $10 \%$ in both HYK and HYK+ cows. Overcrowding can limit the ability of cows to access their desired resources, whether that be lying areas, feed, or water, at the times they would prefer. This has the potential to decrease lying time (Munksgaard et al., 2005) and may impel cows to lie down sooner after milking (Fregonesi et al., 2007), rather than consume feed at the feed bunk, potentially limiting DMI. Proudfoot et al. (2009) demonstrated that when subjected to a competitive feeding environment, multiparous cows showed a decrease in DMI 1 wk before calving. It should be noted that both stall stocking density and feed bunk stocking density were highly variable among the study farms. However, in general, more space was provided on these farms than typically seen on commercial dairy farms for transition cows (von Keyserlingk et al., 2012). In any case, these results suggest that dry cow management should aim to reduce competition for resources by reducing stocking density in close-up dry cow pens.

\section{CONCLUSIONS}

Primiparous cows showed no difference in rumination time between health statuses; however, multiparous cows with ketosis, with or without other health problems, were found to ruminate less than healthy multiparous cows. Higher rumination times during the week before calving and the week after calving were associated with decreased odds of HYK and HYK+, respectively, in multiparous cows. Other factors that were found to decrease the odds of SCK in multiparous cows included lower stall stocking density during the 
week before calving, lower parity, shorter dry period, lower milk yield during the previous lactation, and smaller loss of BCS over the transition period. These results suggest that rumination monitoring across the transition period may contribute to the identification of multiparous cows either at risk for developing SCK or those that have SCK in combination with another health problem. To use rumination data to help identify multiparous cows at risk for developing subclinical ketosis after calving, it is important to begin monitoring rumination during the dry period to establish a baseline for each cow.

\section{ACKNOWLEDGMENTS}

We thank all participating farms for allowing us to collect data on their herds. We are grateful to Robin Crossley, Lisa Gordon, Morgan Overvest, Caylie Corvinelli, and Hannah Gillespie of the University of Guelph, Kemptville Campus (Kemptville, ON, Canada) for all their technical help during data collection. Financial support for this research was received from the Natural Sciences and Engineering Research Council (Ottawa, ON, Canada), as well as from the Ontario Ministry of Agriculture Food University of Guelph Research Partnership (Guelph, ON, Canada). We thank Karen Beauchemin of Agriculture and Agri-Food Canada (Lethbridge, AB, Canada) for providing rumination monitoring equipment, as well as Eastgen (Guelph, ON, Canada), particularly Mark Carson, for contributions towards the rumination monitoring equipment and technical support.

\section{REFERENCES}

Abramson, J. H. 2011. WINPEPI updated: Computer programs for epidemiologists, and their teaching potential. Epidemiol. Perspect. Innov. 8:1.

Adin, G., R. Solomon, M. Nikbachat, A. Zenou, E. Yosef, A. Brosh, A. Shabtay, S. J. Mabjeesh, I. Halachmi, and J. Miron. 2009. Effect of feeding cows in early lactation with diets differing in roughageneutral detergent fiber content on intake behavior, rumination, and milk production. J. Dairy Sci. 92:3364-3373. http://dx.doi. org/10.3168/jds.2009-2078.

AOAC International. 2000. Official Methods of Analysis. 17th ed. Vol. 1. AOAC Int., Arlington, VA.

Andersson, L. 1988. Subclinical ketosis in dairy cows. Vet. Clin. North Am. Food Anim. Pract. 4:233-251.

Bauman, D. E., and W. B. Currie. 1980. Partitioning of nutrients during pregnancy and lactation: A review of mechanisms involving homeostasis and homeorhesis. J. Dairy Sci. 63:1514-1529. http:// dx.doi.org/10.3168/jds.S0022-0302(80)83111-0.

Beauchemin, K. A., B. I. Farr, L. M. Rode, and G. B. Schaalje. 1994. Effects of alfalfa silage chop length and supplementary long hay on chewing and milk production of dairy cows. J. Dairy Sci. 77:1326-1339. http://dx.doi.org/http://dx.doi.org/10.3168/jds. S0022-0302(94)77072-7.

Beauchemin, K. A., and L. M. Rode. 1994. Compressed baled alfalfa hay for primiparous and multiparous dairy cows. J. Dairy Sci. 77:10031012. http://dx.doi.org/10.3168/jds.S0022-0302(94)77036-3.
Beauchemin, K. A., and W. Z. Yang. 2005. Effects of physically effective fiber on intake, chewing activity, and ruminal acidosis for dairy cows fed diets based on corn silage. J. Dairy Sci. 88:21172129. http://dx.doi.org/10.3168/jds.S0022-0302(05)72888-5.

Berge, A. C., and G. Vertenten. 2014. A field study to determine the prevalence, dairy herd management systems, and fresh cow clinical conditions associated with ketosis in western European dairy herds. J. Dairy Sci. 97:2145-2154. http://dx.doi.org/10.3168/ jds.2013-7163.

Calamari, L., N. Soriani, G. Panella, F. Petrera, A. Minuti, and E. Trevisi. 2014. Rumination time around calving: An early signal to detect cows at greater risk of disease. J. Dairy Sci. 97:3635-3647. http://dx.doi.org/10.3168/jds.2013-7709.

Clément, P., R. Guatteo, L. Delaby, B. Rouillé, A. Chanvallon, J. M. Philipot, and N. Bareille. 2014. Short communication: Added value of rumination time for the prediction of dry matter intake in lactating dairy cows. J. Dairy Sci. 97:6531-6535. http://dx.doi. org/10.3168/jds.2013-7860.

Dado, R. G., and M. S. Allen. 1995. Intake limitations, feeding behavior, and rumen function of cows challenged with rumen fill from dietary fiber or inert bulk. J. Dairy Sci. 78:118-133. http://dx.doi. org/10.3168/jds.S0022-0302(95)76622-X.

Dohoo, I. R., S. W. Martin, A. H. Meek, and W. C. D. Sandals. 1983. Disease, production and culling in Holstein Friesian cows. Prev. Vet. Med. 1:321-334

Drackley, J. K. 1999. Biology of dairy cows during the transition period: The final frontier? J. Dairy Sci. 82:2259-2273.

Duffield, T. 2000. Subclinical ketosis in lactating dairy cattle. Vet. Clin. North Am. Food Anim. Pract. 16:231-253.

Duffield, T. F., K. D. Lissemore, B. W. McBride, and K. E. Leslie. 2009. Impact of hyperketonemia in early lactation dairy cows on health and production. J. Dairy Sci. 92:571-580.

Fleischer, P., M. Metzner, M. Beyerbach, M. Hoedemaker, and W. Klee. 2001. The relationship between milk yield and the incidence of some diseases in dairy cows. J. Dairy Sci. 84:2025-2035. http:// dx.doi.org/10.3168/jds.S0022-0302(01)74646-2.

Flower, F. C., and D. M. Weary. 2006. Effect of hoof pathologies on subjective assessments of dairy cow gait. J. Dairy Sci. 89:139-146. http://dx.doi.org/10.3168/jds.S0022-0302(06)72077-X.

Fregonesi, J. A., C. B. Tucker, and D. M. Weary. 2007. Overstocking reduces lying time in dairy cows. J. Dairy Sci. 90:3349-3354. http://dx.doi.org/10.3168/jds.2006-794.

Geishauser, T., K. Leslie, D. Kelton, and T. Duffield. 1998. Evaluation of five cowside tests for use with milk to detect subclinical ketosis in dairy cows. J. Dairy Sci. 81:438-443. http://dx.doi. org/10.3168/jds.S0022-0302(98)75595-X.

Goldhawk, C., N. Chapinal, D. M. Veira, D. M. Weary, and M. A. G. von Keyserlingk. 2009. Prepartum feeding behavior is an early indicator of subclinical ketosis. J. Dairy Sci. 92:4971-4977. http:// dx.doi.org/10.3168/jds.2009-2242.

González, L. A., B. J. Tolkamp, M. P. Coffey, A. Ferret, and I. Kyriazakis. 2008. Changes in feeding behavior as possible indicators for the automatic monitoring of health disorders in dairy cows. J. Dairy Sci. 91:1017-1028. http://dx.doi.org/10.3168/jds.2007-0530.

Grant, R. J., and J. L. Albright. 1995. Feeding behavior and management factors during the transition period in dairy cattle. J. Anim. Sci. 73:2791-2803.

Gröhn, Y. T., S. W. Eicker, and J. A. Hertl. 1995. The association between previous 305-day milk yield and disease in New York State dairy cows. J. Dairy Sci. 78:1693-1702. http://dx.doi.org/10.3168/ jds.S0022-0302(95)76794-7.

Grummer, R. R. 1995. Impact of changes in organic nutrient metabolism on feeding the transition dairy cow. J. Anim. Sci. 73:28202833.

Hayirli, A., R. R. Grummer, E. V. Nordheim, and P. M. Crump. 2002. Animal and dietary factors affecting feed intake during the prefresh transition period in Holsteins. J. Dairy Sci. 85:3430-3443. http://dx.doi.org/10.3168/jds.S0022-0302(02)74431-7.

Huzzey, J. M., D. M. Veira, D. M. Weary, and M. A. G. von Keyserlingk. 2007. Prepartum behavior and dry matter intake identify 
dairy cows at risk for metritis. J. Dairy Sci. 90:3220-3233. http:// dx.doi.org/10.3168/jds.2006-807.

Iwersen, M., U. Falkenberg, R. Voigtsberger, D. Forderung, and W. Heuwieser. 2009. Evaluation of an electronic cowside test to detect subclinical ketosis in dairy cows. J. Dairy Sci. 92:2618-2624. http://dx.doi.org/10.3168/jds.2008-1795.

Kononoff, P. J., A. J. Heinrichs, and H. A. Lehman. 2003. The effect of corn silage particle size on eating behavior, chewing activities, and rumen fermentation in lactating dairy cows. J. Dairy Sci. 86:33433353. http://dx.doi.org/10.3168/jds.S0022-0302(03)73937-X.

LeBlanc, S. 2010. Monitoring metabolic health of dairy cattle in the transition period. J. Reprod. Dev. 56:S29-S35. http://dx.doi. org/10.1262/jrd.1056S29.

Liboreiro, D. N., K. S. Machado, P. R. B. Silva, M. M. Maturana, T. K. Nishimura, A. P. Brandão, M. I. Endres, and R. C. Chebel. 2015. Characterization of peripartum rumination and activity of cows diagnosed with metabolic and uterine diseases. J. Dairy Sci. 98:6812-6827. http://dx.doi.org/10.3168/jds.2014-8947.

Maekawa, M., K. A. Beauchemin, and D. A. Christensen. 2002. Chewing activity, saliva production, and ruminal $\mathrm{pH}$ of primiparous and multiparous lactating dairy cows. J. Dairy Sci. 85:1176-1182. http://dx.doi.org/10.3168/jds.S0022-0302(02)74180-5.

Mashek, D. G., and D. K. Beede. 2001. Peripartum responses of dairy cows fed energy-dense diets for 3 or 6 weeks prepartum. J. Dairy Sci. 84:115-125. http://dx.doi.org/10.3168/jds.S00220302(01)74459-1.

McArt, J. A. A., D. V. Nydam, and G. R. Oetzel. 2012. Epidemiology of subclinical ketosis in early lactation dairy cattle. J. Dairy Sci. 95:5056-5066. http://dx.doi.org/10.3168/jds.2012-5443.

Munksgaard, L., M. B. Jensen, L. J. Pedersen, S. W. Hansen, and L. Matthews. 2005. Quantifying behavioural priorities-Effects of time constraints on behaviour of dairy cows, Bos taurus. Appl. Anim. Behav. Sci. 92:3-14. http://dx.doi.org/10.1016/j. applanim.2004.11.005.

NRC. 2001. Nutrient Requirements of Dairy Cattle. 7th rev. ed. Natl. Acad. Sci., Washington, DC.

Nordlund, K. V. 2009. The five key factors in transition cow management of freestall dairy herds. Pages 27-32 in Proc. 46th Dairy Prod. Conf., Gainesville, FL. University of Florida, Gainesville.

Okine, E. K., and G. W. Mathison. 1991. Effects of feed intake on particle distribution, passage of digesta, and extent of digestion in the gastrointestinal tract of cattle. J. Anim. Sci. 69:3435-3445.

Proudfoot, K. L., D. M. Veira, D. M. Weary, and M. A. G. von Keyserlingk. 2009. Competition at the feed bunk changes the feeding, standing, and social behavior of transition dairy cows. J. Dairy Sci. 92:3116-3123. http://dx.doi.org/10.3168/jds.2008-1718.

Schirmann, K., N. Chapinal, D. M. Weary, W. Heuwieser, and M. A. G. von Keyserlingk. 2012. Rumination and its relationship to feeding and lying behavior in Holstein dairy cows. J. Dairy Sci. 95:3212-3217. http://dx.doi.org/10.3168/jds.2011-4741.

Schirmann, K., N. Chapinal, D. M. Weary, L. Vickers, and M. A. G. von Keyserlingk. 2013. Short communication: Rumination and feeding behavior before and after calving in dairy cows. J. Dairy Sci. 96:7088-7092. http://dx.doi.org/10.3168/jds.2013-7023.

Schirmann, K., M. A. G. von Keyserlingk, D. M. Weary, D. M. Veira, and W. Heuwieser. 2009. Technical note: Validation of a system for monitoring rumination in dairy cows. J. Dairy Sci. 92:6052-6055. http://dx.doi.org/10.3168/jds.2009-2361.
Soriani, N., G. Panella, and L. Calamari. 2013. Rumination time during the summer season and its relationships with metabolic conditions and milk production. J. Dairy Sci. 96:5082-5094. http:// dx.doi.org/10.3168/jds.2013-6620.

Soriani, N., E. Trevisi, and L. Calamari. 2012. Relationships between rumination time, metabolic conditions, and health status in dairy cows during the transition period. J. Anim. Sci. 90:4544-4554. http://dx.doi.org/10.2527/jas.2012-5064.

Sovani, S., C. Heuer, W. M. VanStraalen, and J. P. T. M. Noordhuizen. 2000. Disease in high producing dairy cows following post parturient negative energy balance. Pages 33-50 in Proc. Annual Meeting of Soc. Vet. Epid. Prev. Med., Edinburgh, UK. Soc. Vet. Epid. Prev. Med., Glasgow, UK.

Suthar, V. S., J. Canelas-Raposo, A. Deniz, and W. Heuwieser. 2013. Prevalence of subclinical ketosis and relationships with postpartum diseases in European dairy cows. J. Dairy Sci. 96:2925-2938. http://dx.doi.org/10.3168/jds.2012-6035.

Vanholder, T., J. Papen, R. Bemers, G. Vertenten, and A. C. B. Berge 2015. Risk factors for subclinical and clinical ketosis and association with production parameters in dairy cows in the Netherlands. J. Dairy Sci. 98:880-888. http://dx.doi.org/10.3168/jds.2014-8362. von Keyserlingk, M. A. G., A. Barrientos, K. Ito, E. Galo, and D. M. Weary. 2012. Benchmarking cow comfort on North American freestall dairies: Lameness, leg injuries, lying time, facility design, and management for high-producing Holstein dairy cows. J. Dairy Sci. 95:7399-7408. http://dx.doi.org/10.3168/jds.2012-5807.

Van Soest, P. J., J. B. Robertson, and B. A. Lewis. 1991. Methods for dietary fiber, neutral detergent fiber, and nonstarch polysaccharides in relation to animal nutrition. J. Dairy Sci. 74:35833597. http://dx.doi.org/http://dx.doi.org/10.3168/jds.S00220302(91)78551-2.

Voyvoda, H., and H. Erdogan. 2010. Use of a hand-held meter for detecting subclinical ketosis in dairy cows. Res. Vet. Sci. 89:344-351. http://dx.doi.org/10.1016/j.rvsc.2010.04.007.

Walsh, R. B., J. S. Walton, D. F. Kelton, S. J. LeBlanc, K. E. Leslie, and T. F. Duffield. 2007. The effect of subclinical ketosis in early lactation on reproductive performance of postpartum dairy cows. J. Dairy Sci. 90:2788-2796. http://dx.doi.org/10.3168/jds.2006560 .

Weary, D. M., J. M. Huzzey, and M. A. G. von Keyserlingk. 2009 Board-invited review: Using behavior to predict and identify ill health in animals. J. Anim. Sci. 87:770-777. http://dx.doi org/10.2527/jas.2008-1297.

Welch, J. G., and A. M. Smith. 1970. Forage quality and rumination time in cattle. J. Dairy Sci. 53:797-800. http://dx.doi.org/10.3168/ jds.S0022-0302(70)86293-2.

Wildman, E. E., G. M. Jones, P. E. Wagner, R. L. Boman, H. F. Troutt, and T. N. Lesch. 1982. A dairy cow body condition scoring system and its relationship to selected production characteristics. J. Dairy Sci. 65:495-501. http://dx.doi.org/10.3168/jds.S00220302(82)82223-6.

Yang, W. Z., and K. A. Beauchemin. 2006. Effects of physically effective fiber on chewing activity and ruminal $\mathrm{pH}$ of dairy cows fed diets based on barley silage. J. Dairy Sci. 89:217-228. http:// dx.doi.org/10.3168/jds.S0022-0302(06)72086-0. 